\title{
Vulnerability of women with human immunodeficiency virus to
} cervical cancer

\author{
Vulnerabilidade das mulheres com vírus da imunodeficiência humana ao câncer de colo do útero \\ Vulnerabilidad de las mujeres con virus de la inmunodeficiencia humana al cáncer de cérvix
}

\author{
Ana Zaiz Flores Teixeira de Carvalho ${ }^{1}$ (D) \\ Ivana Cristina Vieira de Lima $^{2}$ (D) \\ Gilmara Holanda da Cunha ${ }^{1}$ (iD \\ Marli Teresinha Gimeniz Galvão ${ }^{1}$ (C) \\ Odaleia de Oliveira Farias ${ }^{1}$ (1)
}

Dayse da Silva Guedes ${ }^{1}$ (1)

1. Universidade Federal do Ceará.

Fortaleza, CE, Brasil.

2. Universidade do Estado do Ceará.

Fortaleza, CE, Brasil.
Corresponding author:

Odaleia de Oliveira Farias.

E-mail: odafarias@hotmail.com

Submitted on $08 / 06 / 2018$.

Accepted on 02/26/2019.

DOI: 10.1590/2177-9465-EAN-2018-0203

\section{Abstract}

Objective: To identify the vulnerabilities of women with human immunodeficiency virus to cervical cancer. Methods: Cross-sectional study carried out in a clinic with 152 adult women with HIV, by means of the application of a structured form comprising several types of vulnerability. Results: Related to individual vulnerability, were prevalent the age above 29 years (87.5\%), education higher than eight years of study (53.3\%) and family income lower than two minimum wages $(94.1 \%)$. The majority reported active sexual life (81.6\%) and non-use of condoms $(57.2 \%)$. Regarding the social vulnerability, $56.6 \%$ were unemployed. About programmatic vulnerability, $44.0 \%$ of women underwent a prevention exam in a period of more than one year. Women with more schooling $(p=0.007)$, employed $(p=0.000)$ and that did not use illicit drugs $(p=0.000)$ underwent the preventive exam in proper frequency. Conclusion: In this study, were identified individual, social and programmatic vulnerabilities for cervical cancer in women with HIV.

Keywords: Vulnerability in health; HIV; Papillomaviridae.

\section{RESUMO}

Objetivo: Identificar as vulnerabilidades das mulheres com vírus da imunodeficiência humana ao câncer de colo do útero. Método: Estudo transversal desenvolvido em ambulatório com 152 mulheres adultas com HIV, a partir de formulário estruturado envolvendo os tipos de vulnerabilidades. Resultados: Para a vulnerabilidade individual, foram predominantes a faixa etária maior que 29 anos (87,5\%), com escolaridade maior que oito anos de estudo $(53,3 \%)$ e renda familiar menor que dois salários mínimos $(94,1 \%)$. A maioria informou vida sexual ativa $(81,6 \%)$ e não utilização de preservativo $(57,2 \%)$. Para vulnerabilidade social, 56,6\% estavam desempregadas. Na vulnerabilidade programática, 44,0\% das mulheres realizaram exame de prevenção em período superior a um ano. Mulheres com maior escolaridade $(p=0,007)$, empregadas $(p=0,000)$ e que não usavam drogas ilícitas $(p=0,000)$ realizavam exames preventivos na frequência adequada. Conclusão: Neste estudo, foram identificadas situações de vulnerabilidades individual, social e programática para câncer de colo do útero nas mulheres com HIV.

Palavras-chave: Vulnerabilidade em saúde; HIV; Papillomaviridae.

\section{REsumen}

Objetivo: Identificar las vulnerabilidades de mujeres con virus de la inmunodeficiencia humana para el cáncer de cérvix. Método: Estudio transversal desarrollado en centro de salud con 152 mujeres con HIV a partir de formulario estructurado envolviendo los tipos de vulnerabilidad. Resultados: Para la vulnerabilidad individual, eran predominantes mujeres con edad superior a 29 años $(87,5 \%)$, escolaridad superior a ocho años $(53,3 \%)$ y renta de la unidad familiar menor que dos salarios mínimos $(94,1 \%)$. La mayoría informó vida sexual activa ( $81,6 \%$ y no uso del preservativo $(57,2 \%)$. Sobre la vulnerabilidad social, $56,6 \%$ estaban desempleadas. Para vulnerabilidad programática, 44,0\% realizaron exámenes preventivos en periodo superior a un año. Mujeres con más escolaridad $(p=0,007)$, empleadas $(p=0,000)$ y que no usaban drogas ilícitas $(p=0,000)$ realizaban exámenes preventivos en la frecuencia adecuada. Conclusión: Se identificaron situaciones de vulnerabilidades individual, social y programática para el cáncer de cérvix en las mujeres con VIH de ese estudio.

Palabras clave: Vulnerabilidad en salud; VIH; Papillomaviridae. 


\section{INTRODUCTION}

Women with Human Immunodeficiency Virus (HIV) are more likely to develop pre-neoplastic and neoplastic cervical lesions caused by Human Papillomavirus (HPV) when compared to seronegative women. ${ }^{1}$ It is estimated that the prevalence of this disease is three times higher in this target group, especially in view of the decrease of CD4+ T lymphocytes and the higher levels of viral load. ${ }^{2}$

The factors that contribute to the greater vulnerability to HPV infection in women with HIV are related to the individual and social aspects, mainly to the multiplicity of sexual partners, early age of the first sexual intercourse, low socioeconomic level and sexual intercourse without the use of the condom. ${ }^{1}$ It should be emphasized that higher level of education and access to information on the diagnosis and prevention of HPV infection in the female population living with HIV contributes to the perception of the risk of cervical cancer precursor lesions (CC) and for adopting health-promoting attitudes. ${ }^{3}$

In the context of health policies, the Clinical Protocol and Therapeutic Guidelines for Management of HIV Infection in Adults, recommends screening CC neoplasia in sexually active HIV-infected women, with a semiannual Pap exam during the first year and if levels of CD4+ T lymphocytes are less than 200 cells, in addition to the annual follow-up in unchanged cases as the main prevention strategy. ${ }^{4}$ Specialized services in HIV/AIDS are the main responsible for guaranteeing the integrality of health care to women living with the virus, therefore, need to ensure the tracking of $\mathrm{CC}$ cases and routing to referral services, in order to promote the health of this woman. However, it is observed in clinical practice the noncompliance with this recommendation, either by the lack of knowledge on the part of women with HIV or by the lack of professionals to provide guidance on the need to systematically carry out the preventive exam. ${ }^{5}$

Educational strategies for health promotion must be present in the work process of all health teams, whether at collective or individual consultation moments. Thus, the dissemination of the need for exams and their periodicity, as well as the warning signs that can mean cancer, are fundamental for the care of women. ${ }^{4}$ Faced with the repercussions of $\mathrm{CC}$ on sexual and reproductive health, the knowledge about vulnerabilities of women with HIV to HPV infection is an important aspect as it contributes to the understanding of how exposure to this health problem occurs in order to identify their health needs from vulnerability markers related to the individual, social and programmatic dimensions.

Individual vulnerability includes biological, personal, risk perception, and self-protection attitudes, which imply increased exposure and susceptibility to a particular condition. Social vulnerability refers to the economic structure, public policies of health and education, culture, ideology and gender relations. Programmatic vulnerability, in turn, is related to public coping policies, their goals, proposed actions, organization and distribution of resources for disease prevention and control. ${ }^{6}$ Understanding the vulnerabilities associated with HIV/HPV coinfection is paramount for the design of comprehensive actions to prevent and treat $\mathrm{CC}$, based on the focus on health education and the organization of the health care network. In view of the above, the present study aimed to identify individual, social and programmatic vulnerabilities to cervical cancer in women with HIV. The hypothesis studied is that women with HIV have all kinds of vulnerabilities to $\mathrm{CC}$ potentiated by their condition.

\section{METHOD}

This is a cross-sectional study, developed in an outpatient service in Fortaleza, Ceará, Brazil, a reference in the care of people with sexually transmitted infections (STIs). This health unit provides service to the spontaneous demand and to the cases referenced by the primary care network, being made available, among other services, the conducting of the diagnostic examinations and the monitoring of the $\mathrm{CC}$.

The sample size was dimensioned to estimate the prevalence of women with HIV/HPV co-infection, with $95 \%$ confidence that the estimation error did not exceed $5 \%$, considering that this prevalence is unknown in the population, being stipulated in $50 \%$ (presumed prevalence), because it provides the largest sample size, and according to the Medical Archive and Statistics Service (MASS) there were a total of 250 women with HIV being attended in the service during the study period. To do so, the following expression was applied:

$$
n=\frac{z^{2} \cdot p \cdot(1-p) \cdot N}{\varepsilon^{2} \cdot(N-1)+z^{2} \cdot p \cdot(1-p)}
$$

In this formula, $z$ equals the value of the $z$ statistic (1.96) for the confidence level adopted (95\%) and $p, N$ and $\varepsilon$ corresponds to the presumed prevalence (0.50), to the population (250) and the tolerable error (0.05), respectively. Thus, a sample of 152 patients was calculated.

The inclusion criteria were: to have a confirmed diagnosis of HIV infection, 18 years or older and to have started sexual activity. Women who were hysterectomized or had any condition that would interfere with communication during the study were excluded. To select the participants, the convenience sampling technique was used. As patients attended the consultation service, they were invited to participate in the study.

Data collection was carried out from July 2015 to January 2016, through an interview in a private environment, using a form based on the types of vulnerability. ${ }^{6}$ In this form, the variables were organized according to the types of vulnerability: 1) Individual vulnerability: age; schooling; family income; viral load; CD4+ T lymphocyte count; use of illicit drugs; cigarettes and alcohol; active sex life; number of sexual partners in the last 12 months; use of condoms in all sexual relations; and previous history of sexually transmitted infections;2) Social vulnerability: labor activity; 3) Programmatic vulnerability: time since the last gynecological prevention exam. Prior to data collection, the form was pre-tested with HIV-positive women, who did not compose the sample. 
For the analysis of the time elapsed since the last CC prevention, the interval of $\leq 1$ and $>1$ year was adopted, due to the time recommended by the Ministry of Health for conducting the examination among women with HIV, since the CC screening in this group should be performed shortly after the beginning of sexual activity, with annual frequency after two consecutive normal exams performed with a half-yearly interval. ${ }^{7}$

The data was organized in Excel for Windows and analyzed using software $R$, version 3.2.2. The absolute and relative frequencies were calculated in addition to the mean and standard deviation. For the analysis of the association between individual/social vulnerability variables and programmatic vulnerability, the chi-square test was used for independent variables. The multivariate analysis was performed based on simple logistic regression, with the calculation of the crude Odds Ratio (OR) and the respective confidence intervals (Cl) of $95 \%$. For logistic regression, the variable "elapsed time since the last CC prevention" was assigned as the dependent, while sociodemographic and clinical variables were considered independent. A value of $p<0.05$ was considered statistically significant.

The study met the ethical and legal aspects of Resolution No. 466/12 of the National Council and Health on research involving human beings. The project was approved by the Research Ethics Committee of the Federal University of Ceará, under protocol No. 953308. All the participants signed the Informed Consent Form (ICF).

\section{RESULTS}

Regarding individual vulnerability, among the 152 women with HIV/AIDS, predominated the age group that was older than 29 years $(87.5 \%)$, education higher than eight years of schooling $(53.3 \%)$ and family income lower than two minimum wages $(94.1 \%)$. The majority had a CD4+ T lymphocyte count $\geq 350$ cells $/ \mathrm{mm}^{3}(80.9 \%)$ and viral load $<400$ copies $/ \mathrm{ml}(88.1 \%)$. A minority reported using cigarettes (11.2\%), illicit drugs (9.2\%) or alcohol (38.2\%). Most of them had an active sex life (81.6\%), and a considerable number reported previous history of sexually transmitted infections ( $44.0 \%$ ). Of a total of $96.0 \%$ reported having had at least one sexual partner in the last 12 months, however, 59 women $(57.2 \%)$ reported not using a condom in all sexual relations (Table 1 ).

Regarding social vulnerability, indicated by the work activity of the participants, $56.6 \%$ of the sample reported being unemployed. Regarding the programmatic vulnerability, represented by the time since the last gynecological prevention, $44.0 \%$ of the women had undergone the last examination in a period of more than one year, being in disagreement with that recommended for women living with HIV/AIDS.

The association between representative variables of individual and social vulnerability, when related to programmatic vulnerability, demonstrated a statistically significant relationship between schooling and the time elapsed since the last gynecological cancer prevention $(p=0.007, \mathrm{OR}=0.391, \mathrm{Cl}=$ $0.200-0.752$ ), proving that women with higher schooling take their preventive exams more regularly. The labor activity was also associated with the time elapsed since the last $\mathrm{CC}$ prevention $(p=0.000, \mathrm{OR}=3.948, \mathrm{Cl}=1.986-8.1333)$, indicating that women with an active labor situation carry out the examination at the appropriate frequency. Women who did not use illicit drugs also performed the test more frequently than those who used these drugs $(p=0.000, \mathrm{OR}=0.057, \mathrm{Cl}=0.002-0.299)$ (Table 2 ).

\section{DISCUSSION}

Women living with HIV/AIDS present high vulnerability to developing CC, because in addition to HIV/HPV coinfection, other individual, social and programmatic factors can increase the chances of developing this disease. ${ }^{5}$ One of the priority scenarios for the development of targeted actions to the prevention of $C C$ is Primary Health Care (PHC), a space where nurses play a leading role, conducting a gynecological nursing consultation among their activities. It should be emphasized that the nursing consultation is an assistance technology in PHC, which has expanded the access and quality of care offered. ${ }^{8}$

Therefore, it should be emphasized that during the nursing consultations of the CC preventive examination to this group, the guidelines given should not be directed only to the collection of material for the cytopathological examination, but also to all aspects of vulnerability that may involve the development of cancer, such as sociodemographic characteristics, life habits, sexual and reproductive history. ${ }^{9}$ The service to this population in $\mathrm{PHC}$ is part of a strategy to reorganize the model of assistance to people living with HIV that brings these individuals closer to the gateways of assistance as well as offering programmatic actions that are sensitive to their condition, based on health promotion, since infection is a chronic condition with a tendency to stabilize its incidence, resulting in a reduction of their vulnerability. ${ }^{10}$

Age is an aspect of individual vulnerability that requires attention in the sample studied, since the incidence of gynecological cancer is high in the age group from 30 to 39 years. ${ }^{7}$ On the other hand, low schooling is related to the lack of knowledge about HPV, in relation to transmission, prevention strategies and association of the virus with CC..$^{9,11,12}$ In the present investigation, the majority of women reported having more than eight years of study, which may facilitate understanding of the guidelines provided during the consultations.

Regarding the financial condition, it was observed that the majority of the women had low family income. Low purchasing power is associated with less capacity for argumentation and negotiation with the partner regarding condom use, making these women more vulnerable to sexually transmitted infections. ${ }^{11} \mathrm{~A}$ study with a similar population found similar results for the average age of women, 37.4 years, low purchasing power $(73.3 \%)$, but lower in schooling $(65.8 \%)$, a factor that reinforces characteristics related to individual vulnerability in this group. ${ }^{13}$ 
Table 1. Aspects of individual vulnerability of women with HIV attended in outpatient health service. Fortaleza, CE, Brazil, 2016.

\begin{tabular}{|c|c|c|}
\hline Individual vulnerability variables & $\mathbf{n}$ & $\%$ \\
\hline \multicolumn{3}{|l|}{ Age (in years) } \\
\hline$\leq 29$ & 19 & 12.5 \\
\hline$>29$ & 133 & 87.5 \\
\hline \multicolumn{3}{|l|}{ Schooling (in years of studying) } \\
\hline$\leq 8$ & 71 & 46.7 \\
\hline$>8$ & 81 & 53.3 \\
\hline \multicolumn{3}{|l|}{ Family Income (in minimum wages)* } \\
\hline$\leq 2$ & 123 & 80.9 \\
\hline$>2$ & 29 & 19.1 \\
\hline \multicolumn{3}{|l|}{ Viral load (copies/ml) } \\
\hline$<400$ & 134 & 88.2 \\
\hline$\geq 400$ & 18 & 11.8 \\
\hline \multicolumn{3}{|l|}{ CD4+ T Lymphocyte count (cells $/ \mathrm{mm}^{3}$ ) } \\
\hline$<350$ & 29 & 19.1 \\
\hline$\geq 350$ & 123 & 80.9 \\
\hline \multicolumn{3}{|l|}{ Use of illicit drugs } \\
\hline Yes & 14 & 9.2 \\
\hline No & 138 & 90.8 \\
\hline \multicolumn{3}{|l|}{ Use of cigarettes } \\
\hline Yes & 17 & 11.2 \\
\hline No & 135 & 88.8 \\
\hline \multicolumn{3}{|l|}{ Alcohol consumption } \\
\hline Yes & 58 & 38.2 \\
\hline No & 94 & 61.8 \\
\hline \multicolumn{3}{|l|}{ Active sex life } \\
\hline Yes & 124 & 81.6 \\
\hline No & 28 & 18.4 \\
\hline \multicolumn{3}{|c|}{ Number of sexual partners in the last 12 months $(n=124)$} \\
\hline 1 & 119 & 78.3 \\
\hline$\geq 2$ & 5 & 21.7 \\
\hline \multicolumn{3}{|c|}{ Condom use in all sexual relations $(n=124)$} \\
\hline Yes & 65 & 42.8 \\
\hline No & 59 & 57.2 \\
\hline \multicolumn{3}{|c|}{ Previous history of sexually transmitted infection } \\
\hline Yes & 67 & 44.1 \\
\hline No & 85 & 55.9 \\
\hline
\end{tabular}

Mean \pm standard deviation: Age (39 \pm 8.3 years); Schooling ( $9 \pm 4$ years); Family Income (1.7 \pm 1.2 minimum wages; * current minimum wage: R\$ 788.00.); CD4+ T lymphocytes $\left(604 \pm 303\right.$ cells $\left./ \mathrm{mm}^{3}\right)$; Viral load $\left(6,010 \pm 40,699\right.$ cells $\left./ \mathrm{mm}^{3}\right)$. 
Table 2. Association and logistic regression between the representative variables of individual/social vulnerability and the related to programmatic vulnerability. Fortaleza, CE, Brazil, 2016.

\begin{tabular}{|c|c|c|c|c|c|}
\hline \multirow{3}{*}{ Variables of individual and social vulnerability } & \multicolumn{3}{|c|}{ Programmatic Vulnerability } & \multirow{3}{*}{ OR } & \multirow{3}{*}{$\mathrm{Cl}(95 \%)$} \\
\hline & \multicolumn{2}{|c|}{$\begin{array}{l}\text { Time since the last } \\
\text { CC*prevention }\end{array}$} & \multirow[t]{2}{*}{$p^{* *}$ value } & & \\
\hline & $\leq 1$ year & $>1$ year & & & \\
\hline \multicolumn{6}{|l|}{ Age (in years) } \\
\hline$\leq 29$ & 12 & 7 & 0.665 & 1.394 & $0.5206-4.019$ \\
\hline$>29$ & 73 & 60 & & 1.000 & Reference \\
\hline \multicolumn{6}{|l|}{ Schooling (in years of studying) } \\
\hline$\leq 8$ & 31 & 40 & 0.007 & 0.391 & $0.200-0.752$ \\
\hline$>8$ & 54 & 27 & & 1.000 & Reference \\
\hline \multicolumn{6}{|l|}{ Family Income (in minimum wages)* } \\
\hline$\leq 2$ & 65 & 58 & 0.172 & 0.511 & $0.205-1.189$ \\
\hline$>2$ & 20 & 9 & & 1.000 & Reference \\
\hline \multicolumn{6}{|l|}{ Viral load (copies/ml) } \\
\hline$<400$ & 78 & 56 & 0.194 & 2.162 & $0.791-6.308$ \\
\hline$\geq 400$ & 7 & 11 & & 1.000 & Reference \\
\hline \multicolumn{6}{|l|}{ CD4+ T Lymphocyte count (cells/mm $\mathrm{mm}^{3}$ ) } \\
\hline$<350$ & 15 & 14 & 0.766 & 0.812 & $0.357-1.856$ \\
\hline$\geq 350$ & 70 & 53 & & 1.000 & Reference \\
\hline \multicolumn{6}{|l|}{ Use of illicit drugs } \\
\hline Yes & 1 & 13 & 0.000 & 0.057 & 0.002-0.299 \\
\hline No & 84 & 54 & & 1.000 & Reference \\
\hline \multicolumn{6}{|l|}{ Use of cigarettes } \\
\hline Yes & 6 & 11 & 0.119 & 0.393 & $0.126-1.112$ \\
\hline No & 79 & 56 & & 1.000 & Reference \\
\hline \multicolumn{6}{|l|}{ Alcohol consumption } \\
\hline Yes & 33 & 25 & 0.982 & 1.064 & $0.549-2.077$ \\
\hline No & 52 & 42 & & 1.000 & Reference \\
\hline \multicolumn{6}{|l|}{ Active sex life } \\
\hline Yes & 73 & 51 & 0.183 & 1.895 & $0.825-4.461$ \\
\hline No & 12 & 16 & & 1.000 & Reference \\
\hline \multicolumn{6}{|c|}{ Number of sexual partners in the last 12 months $(n=124)$} \\
\hline 1 & 70 & 49 & 0.709 & 1.000 & Reference \\
\hline$\geq 2$ & 2 & 3 & & 2.082 & $0.306-18.464$ \\
\hline \multicolumn{6}{|l|}{ Condom use in all sexual relations $(n=124)$} \\
\hline Yes & 39 & 26 & 0.932 & 1.000 & Reference \\
\hline No & 34 & 25 & & 1.102 & $0.535-2.271$ \\
\hline \multicolumn{6}{|l|}{ Previous history of sexually transmitted infection } \\
\hline Yes & 34 & 33 & 0.329 & 0.689 & $0.358-1.318$ \\
\hline No & 51 & 34 & & 1.000 & Reference \\
\hline \multicolumn{6}{|l|}{ Work activity } \\
\hline Yes & 49 & 17 & 0.000 & 3.948 & $1.986-8.133$ \\
\hline No & 36 & 50 & & 1.000 & Reference \\
\hline
\end{tabular}

* CC: Cervical cancer; ${ }^{* *}$ Chi-square test for independent variables. 
In women living with HIV/AIDS, we must consider, in addition to the cytological control with the collection of the gynecological prevention exam, the immunological evaluation, involving CD4+ $T$ lymphocyte counts and viral load, since it is demonstrated an association between HIV with the persistence of HPV, development of cervical intraepithelial neoplasia, risk of HPV infection, and cytological abnormalities. ${ }^{14-18}$ Women with severe immunosuppression and CD4+ T lymphocyte counts below 200 cells $/ \mathrm{mm}^{3}$ have an even greater risk of developing cervical intraepithelial neoplasia ${ }^{14-18}$ where immunosuppression is a predictor of the development of cervical lesion in women with HIV/AIDS, however, the use of antiretroviral therapy may strengthen the immune response and may be a protective factor for these women. ${ }^{19,20}$

Considering HPV as the main risk factor for the development of $\mathrm{CC}$, studies point to the strong association of harmful habits such as smoking, alcohol use and other drugs with high-risk of HPV infection. ${ }^{15,21}$ Women living with HIV and using tobacco have a prevalence of cervical intraepithelial neoplasia four times higher than non-smokers. ${ }^{22}$ The use of alcohol and illicit drugs is associated with a significantly greater risk of acquiring sexually transmitted infections, in the occurrence of unprotected sexual practices. ${ }^{23,24}$ In this study, the majority of women were not vulnerable to alcohol, tobacco and illicit drug use.

In addition to the above factors, active sexual life and the number of sexual partners in the last 12 months also increase the vulnerability of women with HIV/AIDS to developing CC. ${ }^{23-28}$ Although active sex life is a potential factor for $\mathrm{CC}$ development, women who have regular sexual activity tend to be more likely to undergo the preventive exam. ${ }^{25}$ The use of condoms was mentioned by most women. It is emphasized that condom use in all sexual relations is indispensable, since it prevents reinfection by HIV and the acquisition of other sexually transmitted infections, besides allowing the control of the unwanted pregnancy. ${ }^{29}$ It is also noted that the occurrence of other sexually transmitted infections is related to a higher incidence and prevalence of HPV infections. ${ }^{30}$

When evaluating the representative variables of individual and social vulnerability, related to programmatic vulnerability, it was observed that women who were enrolled, who did not use illicit drugs and had an active work situation, had undergone the prevention exam in the last year. The lack of knowledge and lack of health education about CC screening in women living with HIV/AIDS means that many do not take the exam at the recommended intervals, searching the health service only when there are signs and symptoms of infections sexually transmitted diseases, making prevention and early detection of this type of cancer difficult and contributing to the increase of the number of cases in this population. ${ }^{25}$

Drug use is a condition of vulnerability and social exclusion, causing greater difficulty in accessing basic services, such as education and health, increasing vulnerability to illness. ${ }^{5}$ In addition, not having a fixed income can also hamper access to health services and women's ability to adopt and maintain health-enhancing behaviors such as adherence to the preventive examination as recommended, as the means of transportation to the health service is one of the barriers that makes it difficult to attend screening visits of the $\mathrm{CC}$, especially for women who live farthest from service. ${ }^{31}$

Understanding the health care of women with HIV/AIDS from their vulnerabilities allows a reflection on the situations that could make them vulnerable to CC. For this to occur, early diagnosis and disease control are necessary to identify cases of predisposition to cancer, as well as to treat early and appropriately. It becomes essential that health services can guarantee the integrality of health actions directed at women living with HIV/AIDS.

Thus, strategies to reduce the prevalence of CC include vaccination against HPV at the appropriate age, as well as at the adult life for women with HIV/AIDS, accessibility for gynecological prevention consultations, control of HIV transmission, and strategies to promote health, targeted at sex education and lifestyle modification. These strategies are important, since women with HIV have low levels of knowledge about the risk of HPV and CC infection, and may not take adequate preventive measures. $^{32}$

\section{CONCLUSION AND IMPLICATIONS FOR PRACTICE}

The earlier the CC prevention strategies are implemented, the better the patient's prognosis. For this reason, this study made it possible to know the different individual, social and programmatic vulnerabilities presented by women with HIV for $\mathrm{CC}$ development. Thus, the identification of potentiated factors of the different types of vulnerabilities to $\mathrm{CC}$ in this population can contribute to the development of actions, programs and policies, aiming to promote their health and prevent diseases.

In addition, through this article we can dispose of subsidies to act more effectively in the health care of women with HIV/AIDS. These findings may provide interventions more directed to the context of these patients, aiming at the reduction of $\mathrm{CC}$ in this population.

Among the limitations of this study was its transversal nature, which is not able to keep up with the changes in knowledge, attitude and practice of women with HIV/AIDS regarding the gynecological prevention exam and the identification of vulnerabilities for sexually transmitted infections. In view of this, it is pointed out the need for longer studies, with the objective of deepening the knowledge about the relation between HIV/AIDS and the vulnerability to $\mathrm{CC}$ among these women.

\section{REFERENCES}

1. Van Aardt MC, Dreyer G, Snyman LC, Richter KL, Becker P, Mojaki SM. Oncogenic and incidental HPV types associated with histologically confirmed cervical intraepithelial neoplasia in HIV-positive and HIVnegative South African women. S Afr Med J [Internet]. 2016 May;106(6). Available from: https:/www.ncbi.nlm.nih.gov/pubmed/27245730. DOI: 10.7196/SAMJ.2016.v106i6.10335 
2. Gaspar J, Quintana SM, Reis RK, Gir E. Sociodemographic and clinical factors of women with HPV and their association with HIV. Rev Latino Am Enferm [Internet]. 2015 Jan/Feb;23(1):74-81. Available from: http://www.scielo.br/scielo.php?script=sci_arttext\&pid =S0104-11692015000100074. DOI: 10.1590/0104-1169.3364

3. Carvalho MCMP, Queiroz ABA. Women with Lesions Precursor of Uterine Cervical Cancer and HPV: Description Socio-economic and Demographic Profile. DST J Bras Doenças Sex Transm [Internet]. 2011;23(1):28-33. Available from: http://www.dst.uff.br/ revista23-1-2-2011/7\%20-\%20Mulheres\%20Portadoras\%20de\%20 Lesoes\%20Precursoras\%20do\%20Cancer\%20do\%20Colo.pdf

4. Ministério da Saúde (BR). Secretaria de Vigilância em Saúde. Departamento de DST, Aids e Hepatites virais. Protocolo Clínico e Diretrizes Terapêuticas para Manejo da Infecção pelo HIV em Adultos. Brasília (DF): Ministério da Saúde; 2018.

5. Bukirwa A, Mutyoba JN, Mukasa NB, Karamagi Y, Odiit M, Kawuma E, et al. Motivations and barriers to cervical cancer screening among HIV infected women in HIV care: a qualitative study. BMC Womens Health [Internet]. 2015 Oct; 15:82. Available from: https://www.ncbi.nlm.nih.gov/ pmc/articles/PMC4603977/. DOI: 10.1186/s12905-015-0243-9

6. Ayres JRCM. Organization of health care actions: models and practices. Saúde Soc [Internet]. 2009 Apr/Jun;18(Suppl 2):11-23. Available from: DOI: 10.1590/S0104-12902009000600003

7. Ministério da Saúde (BR). Instituto Nacional de Câncer José Alencar Gomes da Silva (INCA). Diretrizes Brasileiras para o Rastreamento do Câncer do Colo do Útero. Rio de Janeiro: INCA; 2011.

8. Dantas CN, Santos VP, Tourinho FSV. A consulta de enfermagem como tecnologia do cuidado à luz dos pensamentos de Bacon e Galimberti. Texto Contexto Enferm [Internet]. 2016;25(1):e2800014. Available from: http://www.scielo.br/scielo.php?pid=S0104$07072016000100601 \&$ script=sci_abstract\&tlng=pt

9. Souza AFS, Costa LHRC. Cervical Cancer and HPV: Women's Knowledge after Nursing Consultation. Rev Bras Cancerol [Internet]. 2015 Oct/Dec;61(4):343-50. Available from: http://pesquisa.bvsalud. org/portal/resource/pt/biblio-847047

10. Ministério da Saúde (BR). Vigilância, Prevenção e Controle das IST, do HIV/Aids e das Hepatites Virais. 5 passos para a implementação do manejo da infecção pelo HIV na Atenção Básica: Guia para Gestores. Brasília (DF): Ministe'rio da Saúde; 2014.

11. Mugweni E, Omar M, Pearson S. Understanding barriers to safer sex practice in Zimbabwean marriages: implications for future HIV prevention interventions. Health Educ Res [Internet]. 2015 Jun;30(3):388-99. Available from: https://www.ncbi.nlm.nih.gov/pubmed/25503579

12. Santos AMR, Holanda JBL, Silva JMO, Santos AAP, Silva EM. Cervical cancer: knowledge and behavior of women for prevention. Rev Bras Promoç Saúde [Internet]. 2015 Apr/Jun;28(2):153-9. Available from: https://periodicos.unifor.br/RBPS/article/view/3066/pdf. DOI: 10.5020/18061230.2015.p153

13. Brito DMS, Galvão MTG, Pereira MLD. Markers of vulnerability for cervical cancer in HIV-infected women. Rev Latino Am Enferm [Internet]. 2011 May/Jun;19(3):500-7. Available from: http://www.scielo.br/scielo. php?script=sci_arttext\&pid=S0104-11692011000300008

14. Camargo M, Soto-De Leon SC, Munoz M, Sanchez R, Peña-Herrera $D$, Pineda-Peña AC, et al. Human papillomavirus detection in women with and without human immunodeficiency virus infection in Colombia. BMC Cancer [Internet]. 2014 Jun;14:451. Available from: https://www. ncbi.nlm.nih.gov/pubmed/24942545. DOI: 10.1186/1471-2407-14-451

15. Martins AES, Lucena-Silva N, Garcia RG, Welkovic S, Barbosa A, Menezes MLB, et al. Prevalence of human papillomavirus infection, distribution of viral types and risk factors in cervical samples from human immunodeficiency virus-positive women attending three human immunodeficiency virus-acquired immune deficiency syndrome reference centres in northeastern Brazil. Mem Inst Oswaldo Cruz [Internet]. 2014 Aug;109(6):738-47. Available from: http://www.scielo. br/scielo.php?script=sci_arttext\&pid=S0074-02762014000600738
16. Dames DN, Blackman E, Butler R, Taioli E, Eckstein S, Devarajan K, et al.; African Caribbean Cancer Consortium. High-risk cervical human papillomavirus infections among human immunodeficiency virus-positive women in the Bahamas. PLoS One [Internet]. 2014 Jan;9(1):e85429. Available from: https://www.ncbi.nlm.nih.gov/pubmed/24465558. DOI 10.1371/journal.pone.0085429

17. Teixeira NCP, Araújo ACL, Correa CM, Lodi CTC, Lima MIM, Carvalho $\mathrm{NO}$, et al. Prevalence and risk factors for cervical intraepithelia neoplasia among HIV-infected women. Braz J Infect Dis [Internet]. $2012 \mathrm{May} / \mathrm{Apr} ; 16(2): 164-9$. Available from: http://www.scielo.br/ scielo.php?script=sci_arttext\&pid=S1413-86702012000200010. DOI 10.1590/S1413-86702012000200010

18. Lofgren SM, Tadros T, Herring-Bailey G, Birdsong G, Mosunjac M, Flowers $L$, et al. Progression and regression of cervical pap test lesions in an urban AIDS clinic in the combined antiretroviral therapy era: a longitudinal, retrospective study. AIDS Res Hum Retroviruses [Internet] 2015 May;5(31):508-13. Available from: https://www.ncbi.nlm.nih.gov/ pubmed/25693769. DOI: 10.1089/AID.2014.0254

19. Zhang HY, Fei MD, Jiang Y, Fei QY, Qian $H$, Xu L, et al. The diversity of human papillomavirus infection among human immunodeficiency virusinfected women in Yunnan, China. Virol J [Internet]. 2014 Dec;11:202. Available from: https://www.ncbi.nlm.nih.gov/pubmed/25481842. DOI 10.1186/s12985-014-0202-3

20. Silveira MP, Silveira CP, Guttier MC, Page K, Moreira LB. Long-term immune and virological response in HIV-infected patients receiving antiretroviral therapy. J Clin Pharm Ther [Internet]. 2016 Dec;41(6):68994. Available from: https://www.ncbi.nlm.nih.gov/pubmed/27676134. DOI: $10.1111 /$ jcpt. 12450

21. Adler DH, Wallace M, Bennie T, Mrubata M, Abar B, Meiring TL, et al. Cervical dysplasia and high-risk human papillomavirus infections among HIV-Infected and HIV-uninfected adolescent females in South Africa. Infect Dis Obst and Gynecol [Internet]. 2014;2014:498048. Available from: https://www.ncbi.nlm.nih.gov/pubmed/25389377. DOI 10.1155/2014/498048

22. de Andrade AC, Luz PM, Velasque L, Veloso VG, Moreira RI, Russomano $F$, et al. Factors associated with colposcopy-histopathology confirmed cervical intraepithelial neoplasia among HIV-infected women from Rio De Janeiro, Brazil. PLoS One [Internet]. 2011 Mar;6(3):e18297. Available from: https://www.ncbi.nlm.nih.gov/pubmed/21479179. DOI: 10.1371/ journal.pone.0018297

23. Duarte MTC, Parada CMGL, Souza LR. Vulnerability of women living with HIV/aids. Rev Latino Am Enferm [Internet]. 2014 Jan/Feb;22(1):68-75. Available from: http://www.scielo.br/scielo.php?script=sci_arttext\&pid =S0104-11692014000100068. DOI: 10.1590/0104-1169.2837.2377

24. Azim T, Bontell I, Strathdee SA. Women, drugs and HIV. International Journal of Drug Policy [Internet]. 2015 Feb;Suppl 1:S16-21. Available from: https://www.ncbi.nlm.nih.gov/pubmed/25277726. DOI: http:// dx.doi.org/10.1016/j.drugpo.2014.09.003.23

25. Medeiros T, Farias MCAD, Sousa AKA, Abreu RMSX, Maracajá PB. Knowledge and perception of women on the preventive examination for cervical cancer. REBES. 2015;5(4):9-16.

26. Barasuol MEC, Schmidt DB. Cervical cancer and its risk factors: integrative review. Rev Saúde Desenvol [Internet]. 2014;6(3):138-53. Available from: https://www.uninter.com/revistasaude/index.php/ saudeDesenvolvimento/article/view/312/228

27. Arruda FS, Oliveira FM, Lima RE, Peres AL. Knowledge and practice in doing the pap smear and HPV infection in adolescents public school. Rev Para Med. 2013;27(4):59-65.

28. Ursu RG, Onofriescu M, Luca A, Prisecariu LJ, Salceanu SO, Nemescu D, et al. The Need for Cervical Cancer Control in HIV-Positive and HIV-Negative Women from Romania by Primary Prevention and by Early Detection Using Clinically Validated HPV/DNA Tests. PLoS One [Internet]. 2015 Jun;10(7):e0132271. Available from: https://www.ncbi. nlm.nih.gov/pubmed/26186361. DOI: 10.1371/journal.pone.0132271 
29. Shewamene Z, Legesse B, Tsega B, Bhagavathula AS, Endale A. Consistent condom use in HIV/AIDS patients receiving antiretroviral therapy in northwestern Ethiopia: implication to reduce transmission and multiple infections. HIV AIDS (Auckl) [Internet]. 2015 pr;7:11924. Available from: https://www.ncbi.nlm.nih.gov/pmc/articles/ PMC4403739/

30. Liu J, Liu W, Liu Y, Zhou X, Zhang Z, Sun Z. Prevalence of microorganisms co-infections in human papillomaviruses infected women in Northern China. Arch Gynecol Obstet [Internet]. 2016 Mar;293(3):595-602. Available from: https://www.ncbi.nlm.nih.gov/ pubmed/26280325. DOI: 10.1007/s00404-015-3826-7
31. Fletcher FE, Buchberg M, Schover LR, Basen-Engquist K, Kempf MC, Arduino RC, et al. Perceptions of barriers and facilitators to cervical cancer screening among low-income, HIV-infected women from an integrated HIV clinic. AIDS Care [Internet]. 2014;26(10):1229-35. Available from: https://www.ncbi.nlm.nih.gov/pubmed/24635664.DOI: 10.1080/09540121.2014.894617

32. Lambert CC, Chandler R, McMillan S, Kromrey J, Johnson-Mallard V Kurtyka D. Pap test adherence, cervical cancer perceptions, and HPV knowledge among HIV-infected women in a community health setting. J Assoc of Nurses AIDS Care [Internet]. 2015 May/Jun;26(3):271-80. Available from: https://www.ncbi.nlm.nih.gov/pubmed/25769754.DOI: 10.1016/j.jana.2014.11.007 